\title{
Dolní Věstonice - Vysoká zahrada: an Integrated Geophysical Survey of an Early Medieval Fortified Settlement
}

\author{
Peter Milo ${ }^{1 *}$, Michaela Prišstáková ${ }^{1}$, Tomáš Tencer ${ }^{1}$, Michal Vágner $^{1}$, Igor Murín ${ }^{2}$ \\ ${ }^{I}$ Department of Archaeology and Museology, Masaryk University, Arne Nováka 1, 60200 Brno, Czech Republic \\ ${ }^{2}$ Archaeological Institute, Slovak Academy of Sciences, Akademická 2, 94921 Nitra, Slovakia
}

\section{A R TICLE INFO}

\section{Article history:}

Received: $19^{\text {th }}$ November 2021

Accepted: $5^{\text {th }}$ January 2022

DOI: http://dx.doi.org/10.24916/iansa.2022.1.5

\section{Keywords:}

Early Medieval Period

fortified settlement

fortification

archaeological excavation

electrical resistivity tomography

ground-penetrating radar survey

magnetometry

\begin{abstract}
A B S T R A C T
The fortified settlement at Dolní Věstonice - Vysoká zahrada belongs to the important Early Medieval centres connected with the establishment of the Přemyslid domain in Moravia. The site functioned as a local administrative and economic centre from about the middle of the $11^{\text {th }}$ century to the end of the $12^{\text {th }}$ century. In written historical sources it was known as Strachotíngrad ("Castrum Strachotín"). Between 1948 and 1986, several minor archaeological excavations were made at this site. Our work's purpose was to gain new knowledge by deploying proven geophysical prospecting methods in archaeology. The first two of these methods, Electrical Resistivity Tomography (ERT) and Groundpenetrating radar (GPR) focused on the rampart. Within the third used method - magnetometry, we focused on the prospection of the inner area of the hillfort. Based on the results, it was possible to identify some of the construction features of the fortification and locate the course of the no longer existing rampart and several settlement structures. At the same time, the geophysical survey also made clear the overall plan of past archaeological excavations.
\end{abstract}

\section{Introduction}

Studying fortified settlements is one of the essential topics in mediaeval archaeology. Research within Moravia (a region located in the eastern half of the Czech Republic) has long tended to concentrate on resolving the issues of important sites related to the existence of the Moravian principality in the $9^{\text {th }}$ and $10^{\text {th }}$ centuries. However, the sites linked to the building of the Přemyslid domain in the $11^{\text {th }}$ and $12^{\text {th }}$ centuries have been investigated to a lesser extent. Moravia was annexed by Bohemia in the first half of the $11^{\text {th }}$ century. This process went hand in hand with the building of an administrative system of fortified points to ensure the execution of Přemyslid princely power in Moravia. This paper presents the results of research into the fortified settlement of Dolní Věstonice - Vysoká zahrada, which represents one such local centre. The present study aims to extend our knowledge with new data acquired with the help of a combination of non-invasive survey methods. The

*Corresponding author. E-mail: peter.milo@mail.muni.cz results of our contribution are summarised and an attempt is made to show them in the context of other well-known facts.

\section{The site and its archaeological excavation}

The fortified settlement of Vysoká zahrada is situated north of the village of Dolní Věstonice. The site used to be surrounded by the Dyje (Thaya) River from its southern side, but since the 1980s the surrounding area has been flooded due to the construction of the Nové Mlýny waterworks (Figure 1). The fortified area of the settlement covers an area of about 1 ha, and preserved ramparts in the northern and western part reach up to $6 \mathrm{~m}$ in height. The southern part of the site was destroyed due to the meandering flow of the Dyje River.

The site was mentioned for the first time by Inocenc Ladislav Červinka in 1928 as a fortified settlement from the time of the Bohemian Duke Břetislav (Červinka, 1928, p.124). The beginning of settlement dates back to the second half of the $10^{\text {th }}$ century (Merrínský, 1986, pp.61-62, p.66). 


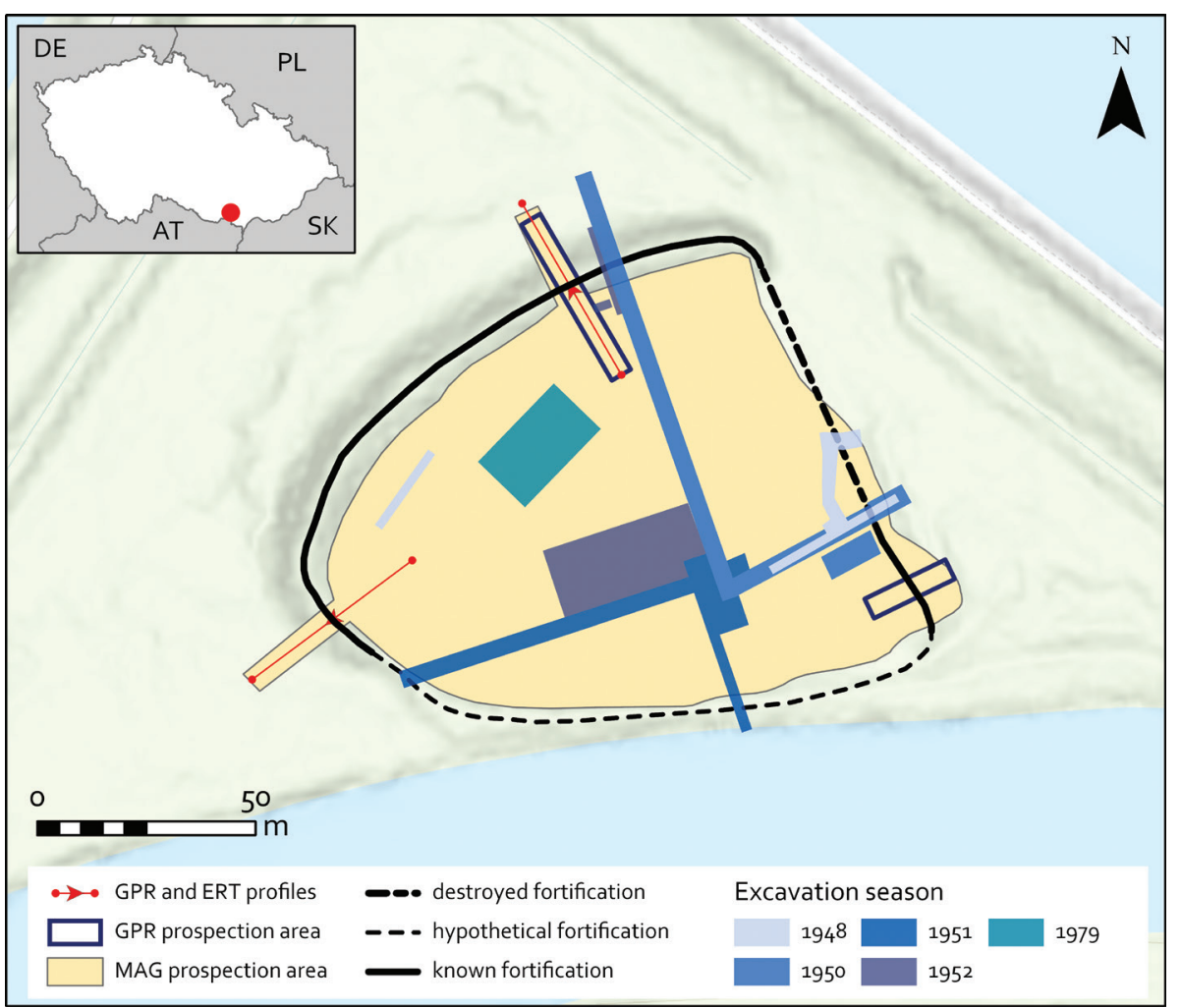

Figure 1. Location of geophysical prospections and archaeological excavations at the Dolní Věstonice - Vysoká zahrada fortified settlement. The polygons of the excavation grid are based on the site reports (Novotný, B., 1982b), results of geophysical prospection and the digital elevation model of the area (background data: ČÚZK).
The fortification is presumed to have been built in the second half of the $11^{\text {th }}$ century (Procházka, 2009, p.134). According to Boris Novotný, it had two construction phases, and the demise of both can be linked to violent events (Novotný, 1982a, pp.325-326, p.333). During the second half of the $11^{\text {th }}$ century, a single-nave stone church with a horseshoeshaped apse was built, and sometime in the middle of the $12^{\text {th }}$ century was surrounded by a wooden palisade. Around this time, a cemetery was established by the church (Jelínková and Kavánová, 2002, p.387). The site is also known from written sources as the Přemyslid administrative centre Strachotíngrad ("Castrum Strachotín"; Fridrich, ed., 1904-1907, pp.254-255, no. 289; Boczek, ed., 1836, p.293, no. 318; Měŕnský, 1985, p.207).

The first archaeological excavations were carried out by Josef Poulík in 1948 and 1950-1952 (Novotný, 1982b). Further field research took place in 1979 by Zdeněk Měřínský (Měřínský, 1981, p.42). He subsequently returned to the site in 1986 due to the damaged fortification in the northeast corner of the site, done by construction workers (Himmelová et. al., 1989, p.56). No archaeological excavation has taken place on the site since then.

Two trial trenches through the fortification were made during the excavations, first in the eastern part, the second in the northern part. In both trenches, remains of wooden beams and strongly burned layers were preserved. In the northern trench, on the outer side of the fortification, a collapsed layer of horizontal wooden beams on the top of an intensely-burned layer was found. In the original body of the rampart, layers of dark and light-coloured clay alternated with layers of grey-black sand occurred. The individual layers were probably separated by an organic layer of wicker or twigs. During the research, fault lines were identified in several places, along which there was a shift of the overlying layers. The construction of the rampart was described as log chamber-bound, without embedded elements into the subsoil (Figure 2; Novotný, 1982b).

Inside the fortified settlement, the dark cultural layer lay under alluvial clay, gravel, and sand. The thickness of the complex of alluvial layers ranges from $60-100 \mathrm{~cm}$, but in some places, it reaches almost 2 m (Měŕnský, 1981, p.42; Novotný, 1982b). The stratigraphy of the site is quite complicated. In various places, two cultural layers (both chronologically dated into the same period) were separated by another alluvial layer. The cultural layer was significantly mixed with carbon, and burnt layers were also found around and in some archaeological features. There were several excavated archaeological structures: a stone church with burial ground with 95 skeletons, a hut, possibly with log construction, several hearths, sunken pits, stone cumulations and stakeholes. One of the excavated features was possibly used for the production of glass rings (Měŕínský, 1985, p.207; Sedláčková and Zapletalová, 2012, p.541).

\section{Location of archaeological excavations}

The site was excavated using long trial trenches, which were subsequently expanded in places where more interesting archaeological situations were captured. Seasons 1948 and 1950 have spatially clear layouts. However, in seasons 1951-1952, spatial references of the excavated fields are 
Figure 2. Dolní Věstonice - Vysoká zahrada. Photography of the west side of the rampart's trial trench situated in the northern part of the site. Black parts of the profile represent strongly-burned layers located on the inner side of the hillfort (Novotný, B. 1982b).

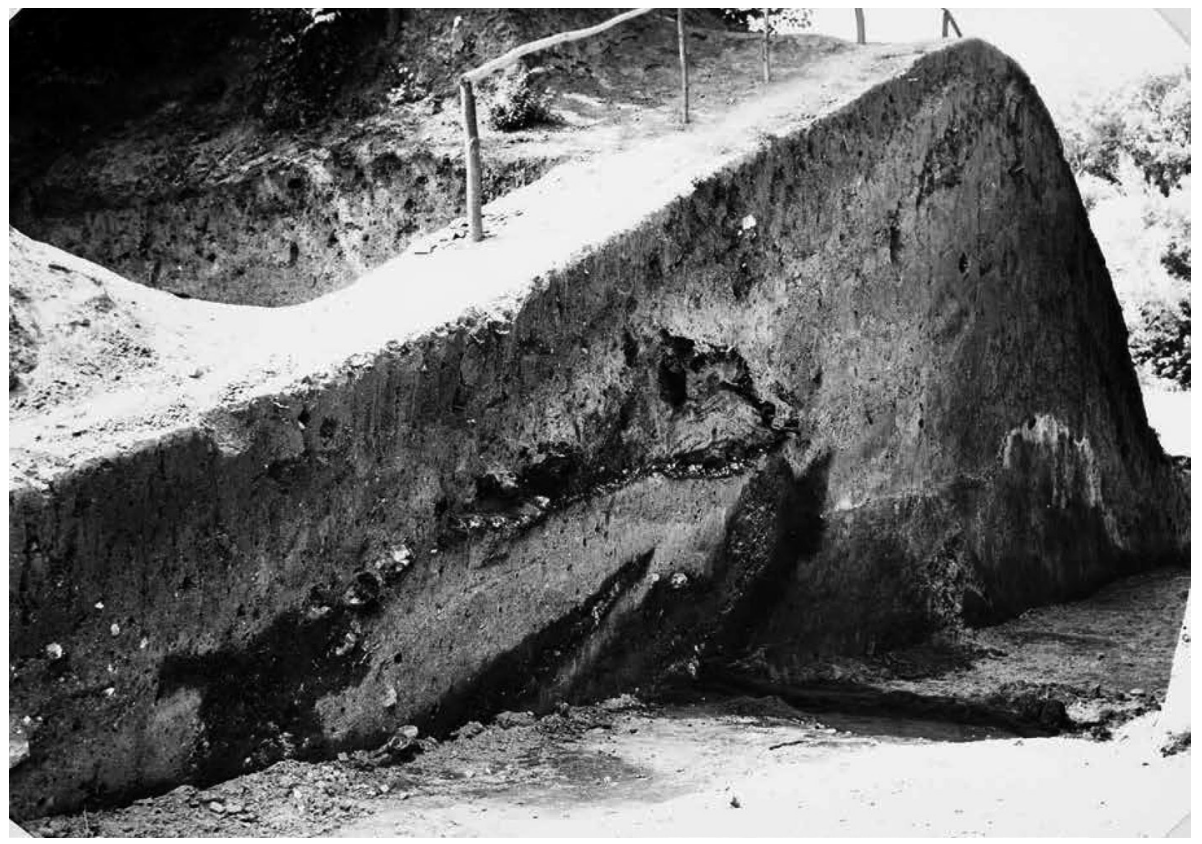

incomplete, and some plans are also missing from site reports. Furthermore, there is no known layout from the 1979 excavation.

To solve the problems associated with the localisation of the surveyed areas, we used available data from the digital elevation model of the $5^{\text {th }}$ generation (DEM), results of magnetic prospection and known descriptions of the excavated areas. In the first step, we georeferenced overall layouts from 1948 and 1950 by DEM. Remnants of the trench, located in the northern part of the fortification, are still visible in the form of a slightly lowered part of otherwise consistent fortification (Figure 3). This observation proved useful as a confirmation between layouts and the contemporary terrain. Subsequently, the plans from the 1951 season were georeferenced, as they are directly linked to the 1950 layouts. Referencing the long trenches from this season was slightly problematic and possibly less accurate. There is no entire layout of the 1951 season, and long trenches are located according to their description in the site reports and their connection to already excavated parts of the site. The main problem was the missing information concerning their length. Therefore, they were reconstructed as was written in the site reports "... on the riverbank, where the fortification is missing" (Novotný, 1982b). The excavation from 1952 has

Figure 3. Dolní Věstonice - Vysoká zahrada. Magnetogram of the surveyed area.

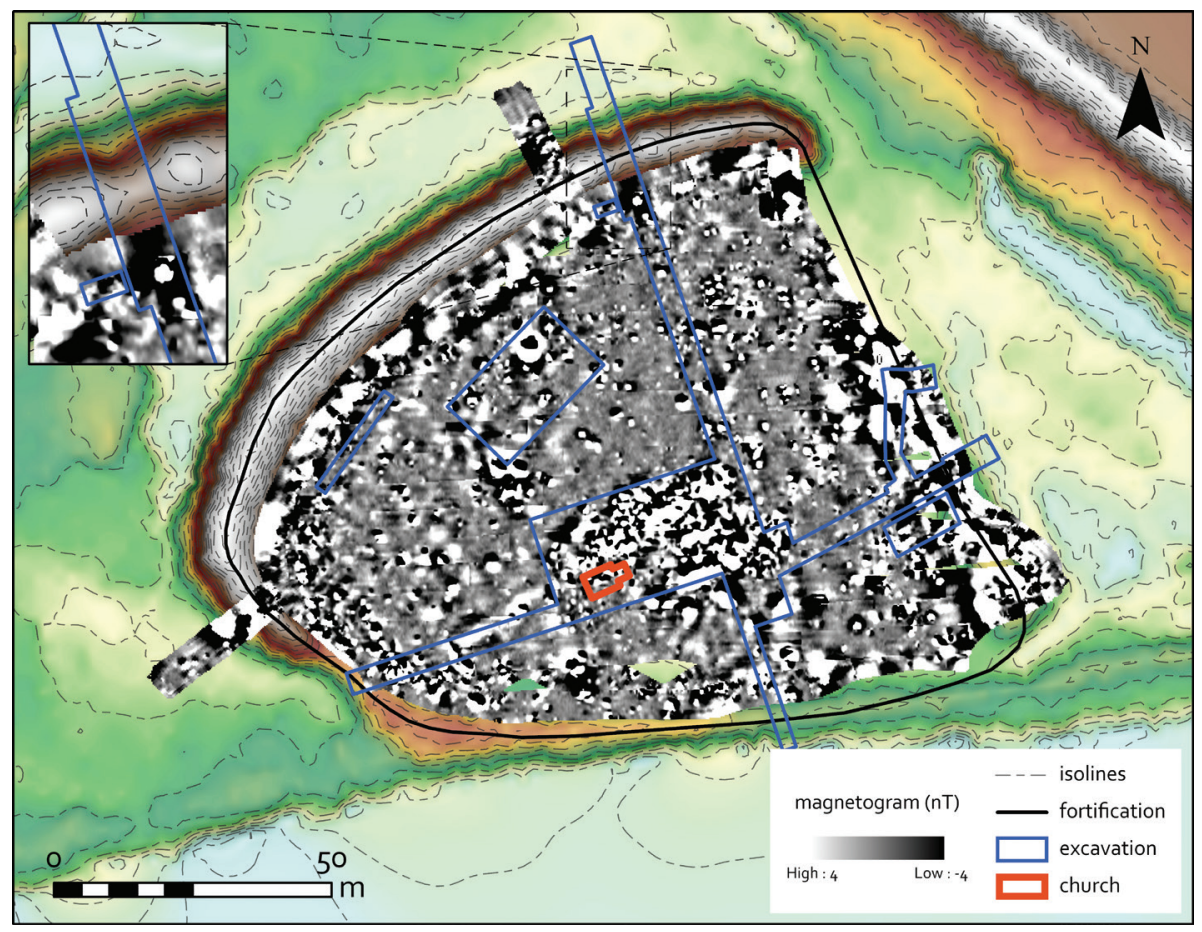




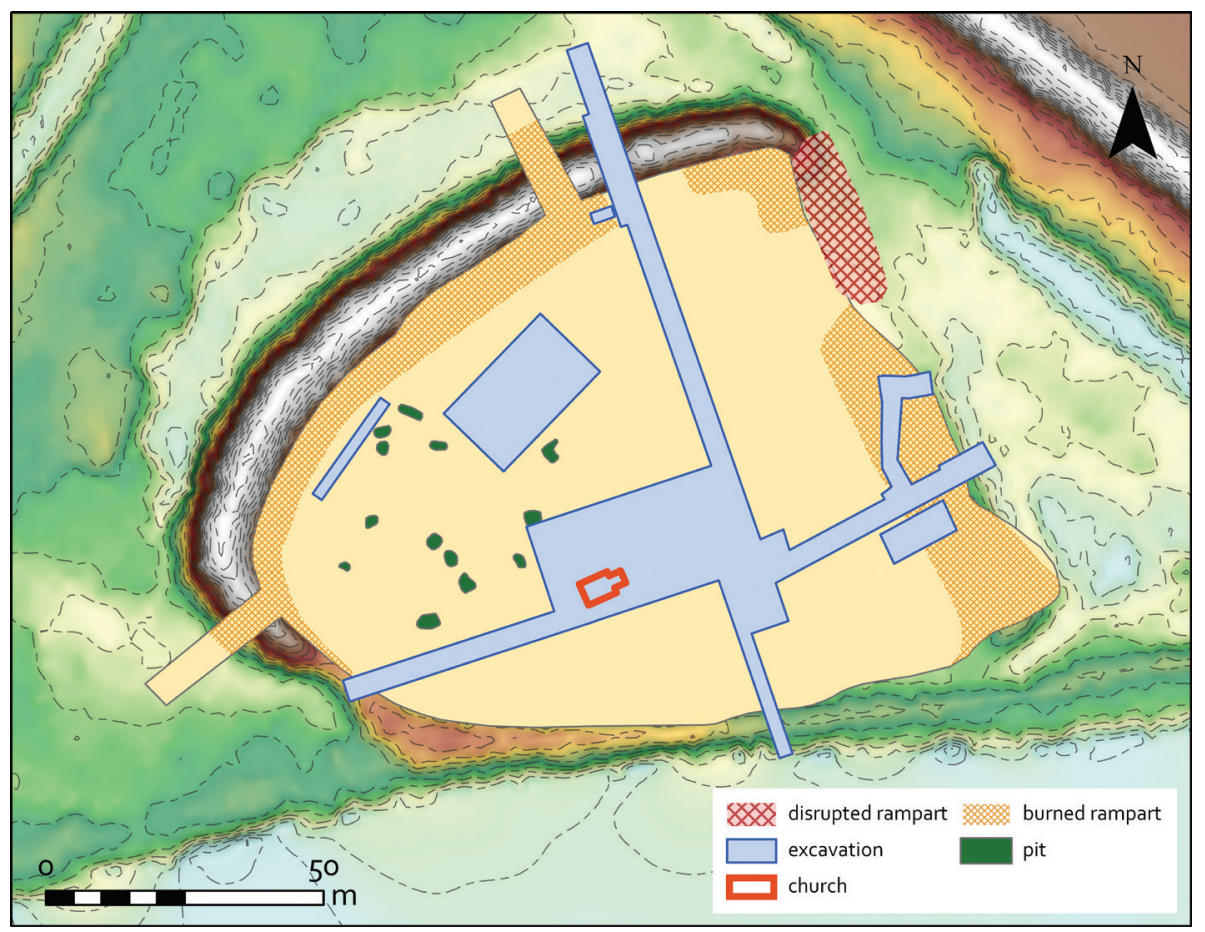

Figure 4. Dolní Věstonice - Vysoká zahrada. Archaeological interpretation of the magnetic prospection data.

known dimensions; nevertheless, its spatial reference was problematic. The excavated area has a partly overlaid area from season 1951, but its extent is not known. Therefore, its location was specified from the magnetometry results, which showed a significant anomaly in the described area with the corresponding dimensions (Figure 3 ). In addition to this, a small test trench was carried out next to the northern fortification trench. It is known only from a description and photographs. Therefore, it was placed in the layout based on its relative position with the fortification trench (Novotný, 1982b). In 1979, another area of the settlement was excavated, but its spatial location was almost entirely unknown. The area is supposed to be in the north-western part of the site (Merrínský 1981, p.42). Based on knowledge from other excavated parts of the site and their record on the magnetogram, we reconstructed the possible location of this excavated area. The magnetogram showed two strong anomalies whose mutual position and dimensions match the known description (Figure 3). Also, knowledge about the changing thickness of the alluvial layers was taken into account. Their thickness decreases in the direction to the fortification and to the north.

\section{Geophysical survey - method, results and analysis}

The geophysical survey aimed to detect subsurface structures and locate areas with potential occurrence of archaeological features and contexts. We selected the most used methods in geophysical archaeological prospection: electrical resistivity tomography (ERT), ground-penetrating radar (GPR), and magnetometry. Nonetheless, each of these methods has its limitations. However, a combination of different methods that examine different physical properties may contribute to a better understanding of an archaeological site (Clark, 1996; Gaffney, 2008; Schmidt et. al., 2016; Scollar et. al., 1990).

For more profound research of buried archaeological features, we selected measurement by the ERT method. The measurement result is a $2 \mathrm{D}$ ERT profile representing the distribution of apparent electrical resistivity $(\Omega \mathrm{m})$ on the profile in both the horizontal and vertical plane (Papadopoulos et. al., 2006; Tsokas et. al., 2009). ERT measurements with the ARES GF instrument (GF INSTRUMENTS) were performed in two places - in the west and north part of the rampart. The lengths of the measured profiles were $47 \mathrm{~m}$. The spacing between the electrodes was $1 \mathrm{~m}$. The Wenner, Schlumberger, and Dipole-Dipole configurations were applied. The RES2DINV program (GEOTOMO) was used to process the measured data. A topographic correction was applied, and a final model representing the real distribution of the specific electrical resistivity in a given profile was created.

The GPR method is based on the repeated transmission of high-frequency electromagnetic pulses to the investigated environment and using the feedback of their response. It works on the principle of monitoring changes in physical quantities in the measured spatial environment, i.e., material differences in the subsoil (permittivity) and specific resistances of individual layers (inhomogeneities) (Conyers and Goodman, 1997; Conyers, 2012). For the GPR survey at Dolní Věstonice, X3M Ramac georadar (Geoscience AB Malå) and two shielded antennas with a central frequency of 250 and $500 \mathrm{MHz}$ were used. In total, three parts of the fortification were surveyed - the southeast part (polygon GPR P1 with length $21 \mathrm{~m}$ and width $5 \mathrm{~m}$ ), northern part (polygon GPR P2 with length $43 \mathrm{~m}$ and width $5 \mathrm{~m}$ ), and western part (profile GPR P3 with length $47 \mathrm{~m}$ ). For the antenna with a central frequency of $250 \mathrm{MHz}$, the distance between the 


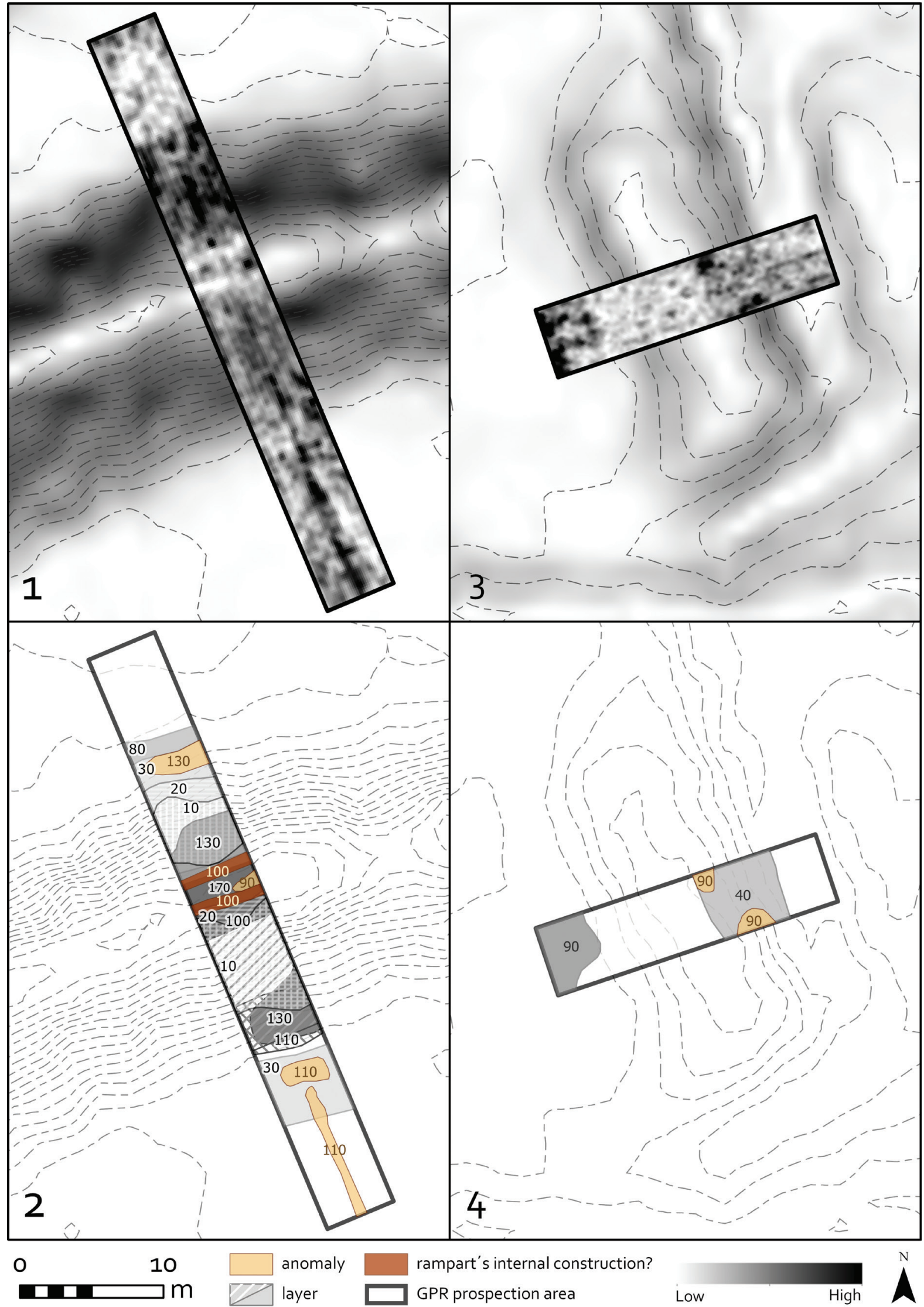

Figure 5. Dolní Věstonice - Vysoká zahrada. 1: Horizontal time slice of surveyed rampart in the north of the fortified settlement (GPR P2; depth 0.9-1.0 m). 2: Interpretation of GPR data from GPR P2. 3: Horizontal time slice of surveyed rampart in the southeast of the fortified settlement (GPR P1; depth 0.9-1.0 m). 4: Interpretation of GPR data from GPR P1. 

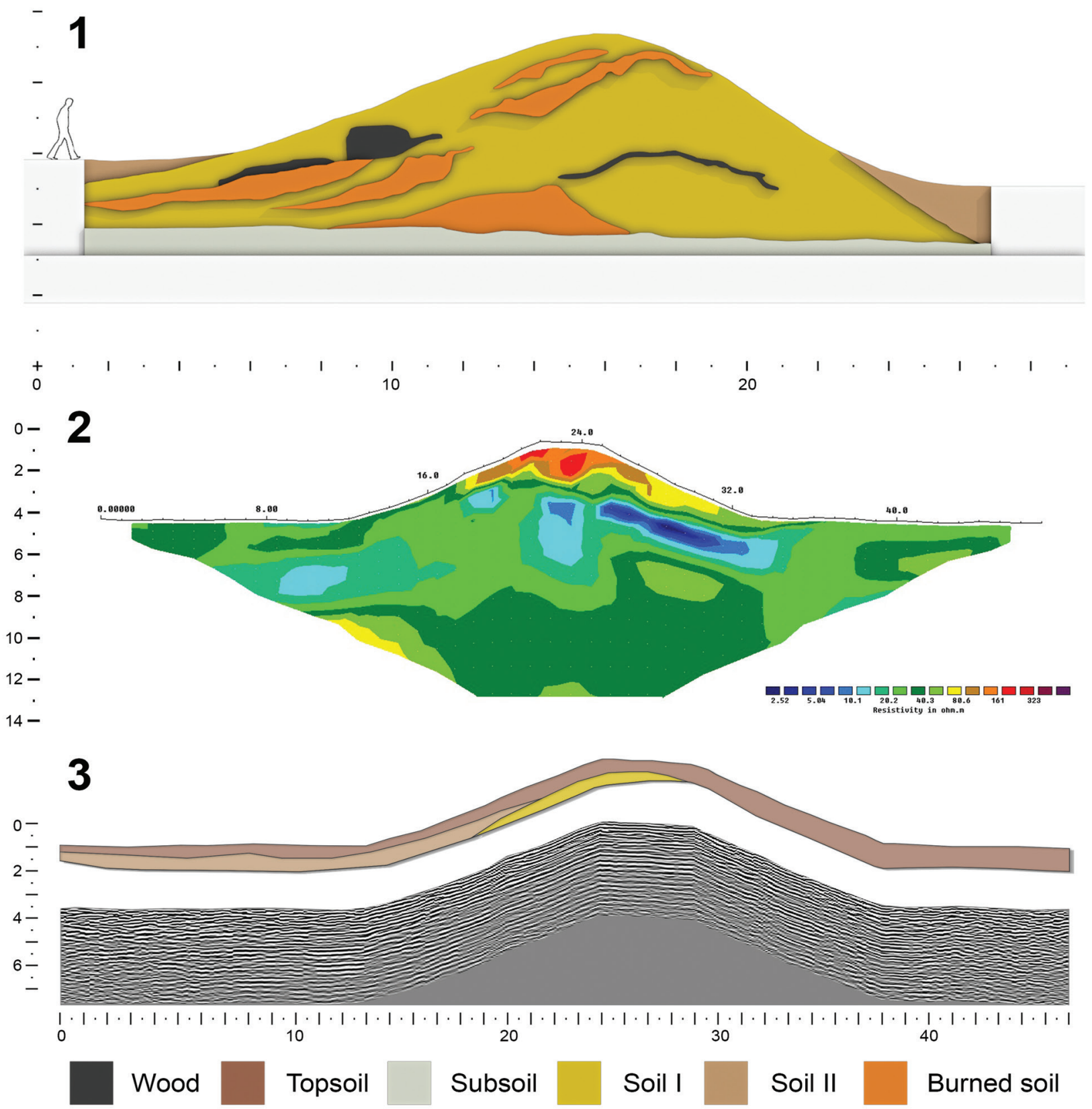

Figure 6. Dolní Věstonice - Vysoká zahrada. 1: Profile of the hillfort's fortification based on the results of archaeological excavations. 2: ERT model in Wenner configuration of the surveyed fortification in the north of the fortified settlement. 3: GPR vertical time/depth slice and its interpretation of the same rampart's section.

profiles was set to $0.5 \mathrm{~m}$, whereas with an antenna with a central frequency of $500 \mathrm{MHz}$ to $0.25 \mathrm{~m}$. The interval of measured points on individual profiles was set to $0.1 \mathrm{~m}$. The topographic data were collected at $1 \mathrm{~m}$ intervals. Multiple data lines collected over an area were processed using GPR Slice software (Geophysical Archaeometry Laboratory). Individual profiles were processed in $\mathrm{Rad}$ Explorer software (Geoscience AB Malå), where standard filters and topographic corrections were applied.

Magnetometry is based on the monitoring of local variations of the Earth's magnetic field. Identified inhomogeneities (magnetic anomalies) are caused by different ratios of ferromagnetic materials in the monitored features and their enclosing soil matrix (Dalan, 2008; Fassbinder and Stanjek, 1993; Fassbinder, 2015; Le Borgne, 1960). The magnetic survey of the site was carried out with a fluxgate magnetometer LEA MAX (Eastern Atlas) with 10 Ferex CON650 (FOERSTER) probes. The density of the magnetic measurements was $0.5 \mathrm{~m}$ on the $\mathrm{X}$-axis and $0.1 \mathrm{~m}$ on the Y-axis (measurement direction). The survey covered the entire suitable terrain (mainly the inner area of the fortified settlement) and two small segments of the rampart 
in the northern and western parts. The total investigated area was 1.03 ha. Measured data were collected with spatial information from the GNSS receiver - Trimble R-10 model 2 (Trimble, USA). Measurement data were processed using standard procedure in the LEAD2 program. ArcGIS Pro 2.8 (ESRI) software was used to present and interpret the results.

GPR and ERT focused on the investigation of the rampart. The first GPR profile (GPR P1) was situated on the southeast side of the stronghold, where the rampart should be originally located. A GPR survey revealed there several inhomogeneous layers (Figure 5). However, it is impossible to determine whether these are remnants of the rampart or just some recently displaced layers. The two remaining profiles (GPR P2 and GPR P3) surveyed the preserved rampart. Homogeneous layers, probably formed only by clay, were identified on both GPR profiles along their entire length (Figures 5 and 6). On the outer side of the ramparts remains, a noticeable homogeneous layer could also be found, which fell away downwards and could be related to the destruction of the ramparts. In addition to a large number of homogeneous layers, which could all be associated with the destruction of the fortification, several linear anomalies located in the body of the rampart were identified in area GPR P2. They stretch parallel to the rampart on its outer side, at a depth of about $1 \mathrm{~m}$ below the level of today's terrain. Their interpretation is unclear, but they are probably remnants of the internal structure of the rampart (Figure 5). The GPR survey did not identify the remains of the ditch in any of the cases investigated.

In both ERT profiles, all three selected configurations recorded similar results. The upper and front part of the bank has higher electrical resistivity values than the central and lower part of the rampart (Figure 6). It is probably due to a sandy soil with a possible mixture of stone. In the lower part, the area is made of a material with very low resistance values. These may be remnants of the original timber structure filled with clay. Approximately in the first third from the inner edge, a slight vertical anomaly with higher values of electric resistivity was visible. We could expect the increased occurrence of wooden structural elements here.

In the magnetic data, the rampart has higher magnetic values (around 50 to $150 \mathrm{nT}$ ) than its surroundings $(0-0.2 \mathrm{nT}$ ) (Figure 3). This is proof that the fortification was subjected to the destructive effects of one or more fires, probably in its entirety and not only in the section that was examined by archaeological excavation. Equally high magnetic values are also shown in the area in front of the fortification, where we can expect layers of the destroyed rampart. The remains of the rampart manifested itself as a significant anomaly in the south-eastern part of the surveyed area. Despite the fact that the rampart is no longer visible in the field, the magnetic survey recorded its course here. The probable reason is that this part of the rampart was also burned down. We did not notice the remains of the rampart on the southern side of the hillfort. Apparently, it was destroyed by the meandering flow of the Dyje River.
The magnetic survey completely covered the inner area of the hillfort. The survey aimed to record potential archaeological features. In addition to the past archaeological excavation mentioned above, the magnetic map is dominated by bipolar magnetic anomalies with high magnetic values (Figure 3). Some of these anomalies can be of archaeological origin, but it is more likely that these are mainly recent iron artefacts. They are scattered all over the area of the stronghold.

We have also registered anomalies that can be described as potential archaeological features. These are characterised by slightly positive magnetic values $(2-10 \mathrm{nT})$. In total, 13 such structures were recorded (Figure 4). Most of them are located in the western part of the fortified settlement. These are features with irregular to round and oval ground plans and dimensions of 3 to $10 \mathrm{~m}^{2}$. The dating and function of these features are unknown. However, we must note that the recorded features undoubtedly represent only a small part of the total number of features on the site. Archaeological excavation allows us to believe that the site's occupation was much denser than the geophysical survey suggests. Unfortunately, the younger alluvial layer, which covered the archaeological situations, caused weak magnetic contrast of the fillings of the potential archaeological features. We cannot even rule out that some of the interpreted archaeological features are structures of pedological origin.

Up to now, our knowledge of the settlement of the fortified settlement in Dolní Věstonice - Vysoká zahrada and its fortification has been based only on the knowledge gained through archaeological excavation. The geophysical survey of the site thus significantly complements the set of existing information. New evidence of settlement activities has been provided by the magnetic research. The GPR and ERT surveys provided new information about the rampart.

The recorded ERT and GPR results confirmed previous findings of archaeological excavation of the fortification. The results of the GPR measurements did not show a muchdifferentiated picture of the internal structure of the rampart. It appears that the rampart body consists only of clay and wood, without the presence of larger stone structures. This result would correspond to the findings of the archaeological excavations (Novotný, 1982a; Novotný, 1982b). The results of the ERT confirm the findings of the GPR survey: the rampart body is relatively homogeneous. Nevertheless, we can observe the possible presence of material with higher resistivity values. Even so, the presence of stone features in the rampart body cannot be completely ruled out.

We have also gathered similar results at other prospected sites. As part of the project, while the fortifications in Dolní Věstonice were being geophysically surveyed, a total of ten early medieval hillforts in southwestern Slovakia and south Moravia were also being subjected to similar research. By combining individual methods, several structural elements have been identified in detail in several ramparts. From the point of view of geophysical measurement results, the rampart in Dolní Věstonice is very similar to the outer rampart of Bailey II in hillfort Brno - Staré Zámky (Milo et. al., 2020a, pp.191-193, Figure 9) and the ramparts 
in Bíňa (Henning and Ruttkay, 2011, pp.273-275). On the other hand, there are fortifications, such as in Svätý Jur Neštich (Milo et. al., 2020b, pp.108-114, Figures 4-8), which exhibit higher electrical resistance values as well as significant inhomogeneities in the GPR survey. It confirms that stone was a very significant building material there.

The geophysical survey has told us very little about the settlement structure. The features identified on the magnetic map represent only a part of the archaeological traces here. That is mostly due to the younger alluvial layers of clay, gravel and sand, which have covered the original settlement horizon (Měřínský, 1981, p.42). We also know of similar situations from other sites, for example, from Majcichov; the magnetic prospection revealed only a few potential features in the inner area of the hillfort. This state is because of an alluvial layer covering the original settlement horizon (Fottová et. al., 2007, pp.224-225 ), which acts as a barrier that does not allow individual settlement features to be identified using the magnetic survey. In the last analysis, further archaeological excavation will be needed to address future issues related to the form and structure of the settlement.

\section{Conclusions}

Our knowledge of the fortified settlement of Dolní Věstonice - Vysoká zahrada has previously been based on data obtained solely from archaeological excavations. The conclusions presented in this paper are based on the results of geophysical surveys conducted in 2019. The aim of the geophysical prospection was to detect subsurface structures in an effort to locate areas with the potential occurrence of archaeological situations in the inner area of the stronghold and define the internal structure of the rampart. The magnetic survey in the inner area of the stronghold confirmed a few archaeological features, which can be interpreted as settlement structures of various kinds. Due to the covering of the original settlement horizon by a thick alluvial layer, we cannot properly define the settlement structure. However, magnetic research has significantly helped to locate past archaeological excavations. The ERT and GPR survey confirmed the results of the archaeological excavation on the character of the fortification. In addition, a magnetic survey found that the entire rampart was probably subjected to fire (one or several fires). In the south-eastern sector of the survey, it was possible to find the course of the now non-existent levelling rampart. In future work, it will be necessary to verify the geophysical results - in this case, a magnetic survey by targeted archaeological excavations, extending them with additional data potentially brought in by large-scale groundpenetrating radar and geoelectric resistivity measurement.

\section{Acknowledgements}

This publication is based on research supported by the Czech Science Foundation (GACR) under Grant No. 18-16153S
"Early medieval strongholds in the light of non-destructive investigation".

\section{References}

BOCZEK, A., ed., 1836: Codex diplomaticus et epistolaris Moraviae I. 396-1199. Olomucii: Anton Friedrich Mittrowsky.

CLARK, A., 1996. Seeing beneath the soil. Prospecting methods in archaeology, London: Routledge.

CONYERS, L.B., 2012. Interpreting ground-penetrating radar for archaeology, Walnut Creek, California: Left Coast Press.

CONYERS, L.B., and GOODMAN, D., 1997. Ground Penetrating Radar An Introduction for Archaeologist, Walnut Creek, California: AltaMira Press.

ČERVINKA, I. L., 1928. Slované na Moravě a řǐse Velkomoravská. Brno: Pravěk.

DALAN, R.A., 2008. A review of the role of magnetic susceptibility in archaeogeophysical studies in the USA: recent developments and prospects. Archaeological Prospection, 15, 1-31.

FASSBINDER, J.W.E., 2015. Seeing beneath the farmland, steppe and desert soil: magnetic prospecting and soil magnetism. Journal of Archaeological Science, 56, 85-95.

FASSBINDER, J.W.E., and STANJEK, H., 1993. Occurrence of bacterial magnetite in soils from archaeological sites. Archaelogia Polonia, 31, $117-128$.

FOTTOVÁ, E., HENNING, J., and RUTTKAY, M., 2007. Archeologický výskum včasnostredovekého hradiska v Majcichove. Archäologische Grabung eines frühmittelaltrelichen Burgwalls in Majcichov. In: K. Pieta, A.T. Ruttkay, and M. Ruttkay, eds. Bojná. Hospodárské a politické centrum nitrianského kniežatstvá. Bojná. Wirtschaftliches und politisches Zentrum Nitraer Fürstentums. Archaeologia Slovaca Monographiae, 9, Nitra: Archeologický ústav Slovenskej akadémie vied, pp. 217-236.

FRIDRICH, G., ed., 1904-1907: Codex diplomaticus et epistolaris regni Bohemiae I. 805-1197. Pragae: Sumptibus Comitiorum Regni Bohemiae.

GAFFNEY, C., 2008. Detecting trends in the prediction of the buried past: A review of geophysical techniques in archaeology. Archaeometry, 50, 313-336.

HENNING, J., and RUTTKAY, M., 2011. Frühmittelalterliche Burgwälle an der mittleren Donau im ostmitteleuropäischen Kontext: Ein deutschslowakisches Forschungsprojekt. In: J. Macháček, and Š. Ungerman, eds. Frühgeschichtliche Zentralorte in Mitteleuropa. Studien zur Archäologie Europas, 14, Bonn: Habelt Verlag, pp. 259-288.

HIMMELOVÁ, Z., KUNDERA, L., and MĚŘÍNSKÝ, Z., 1989. Grabungauf dem Burgwall ,Vysoká zahrada‘ bei Dolní Věstonice (Bez. Břeclav). Přehled výzkumů, 31, 56.

JELÍNKOVÁ, D., and KAVÁNOVÁ, B., 2002. Slovanské osídlení v oblasti vodního díla Nové Mlýny. In: S. Stuchlík, ed. Oblast vodního díla Nové Mlýny od pravěku do středověku. Brno: Archeologický ústav AV ČR, Brno.

LE BORGNE, E., 1960. Influence du feu sur les propriétés magnétiques du sol et sur celles du schiste et du granite. Annales de Géophysique, 16, 159-195.

MĚŘÍNSKÝ, Z. 1981. Výzkum hradišt' 'Petrova louka' u Strachotína a 'Vysoká zahrada' u Dolních Věstonic v roce 1979 (okr. Břeclav). Přehled výzkumů, 24, 41-42.

MĚŘíNSKÝ, Z. 1985. Archeologická topografie katastrálních území obcí v oblasti vodního díla Nové Mlýny (okres Břeclav). Jižní Morava, 21, 205-220.

MĚŘÍNSKÝ, Z. 1986. Morava v 10. století ve světle archeologických nálezů. Památky archeologické, 77, 18-80.

MILO, P., TENCER, T., VÁGNER, M., PRIŠŤÁKOVÁ, M., and MURÍN, I. 2020a. Geophysical Survey of the Hillfort Staré Zámky near BrnoLíšeň, Czech Republic. Interdisciplinaria Archaeologica, Natural Sciences in Archaeology, 11(2), 183-195.

MILO, P., VAVÁK, J., VÁGNER, M., PRIŠŤÁKOVÁ, M., MURÍN, I., and TENCER, T., 2020b. Svätý Jur-Hillfort Neštich - new insights on the settlement and fortification of the early medieval hillfort. Studijné zvesti Archeologického ústavu SAV, 67, 103-127. 
NOVOTNÝ, B., 1982a. K problematice způsobu výstavby opevnění nížinného hradiště Strachotína - Vysoké Zahrady u Dolních Věstonic na Moravě. Archaeologia historica, 7, 325-334.

NOVOTNÝ, B., 1982b. Nálezová zpráva, č. j. 366/54. Manuscript deposited in the Archive of the Archaeological Institute of the Czech Academy of Sciences in Brno.

PAPADOPOULOS, N.G., TSOURLOS, P., TSOKAS, G.N., and SARRIS, A. 2006. Two dimensional and three-dimensional resistivity imaging in archaeological site investigation. Archaeological Prospection. Archaeological Prospection, 13, 163-181.

PROCHÁZKA, R., 2009. Vývoj opevňovaci techniky na Moravě a v českém Slezsku v raném středověku, Brno: Archeologický ústav Akademie věd České republiky, Brno.

SCOLlAR, I., TABBAGH, A., HESSE, A., and HERZOG, I., 1990. Archaeological prospecting and remote sensing, Cambridge: Cambridge University Press.
SEDLÁČKOVÁ, L., and ZAPLETALOVÁ, D., 2012. Skleněné kroužky z Brna a problematika raně středověkého sklářství na Moravě. Archeologické rozhledy, 64, 534-548.

SCHMIDT, A., LINFORD, P., LINFORD, N., DAVID, A., GAFFNEY, C., SARRIS, A., and FASSBINDER, J.W.E., 2016. EAC guidelines for the use of geophysics in archaeology: Questions to ask and points to consider, Namur: Europae Archaeologiae Consilium.

TSOKAS, G.N., TSOURLOS, P.I., and PAPADOPOULOS, N., 2009. Electrical resistivity tomography: A flexible technique in solving problems of archaeological research. In: S. Campana, and S. Piro, eds. Seeing the unseen. Geophysics and landscape archaeology. London: CRC Press, pp. 83-104. 
